\title{
Kinerja perawat di ruangan rawat inap Rumah Sakit Bhayangkara Tingkat II Medan ditinjau dari kompetensi, motivasi dan beban kerja
}

\author{
Danar Michael Halawa, Thomson Parluhutan Nadapdap, Mangatas Silaen \\ Institut Kesehatan Helvetia \\ *Korespondensi: danarmichaelhalawa@gmail.com \\ DOI: 10.34012/jpms.v2i2.1455 \\ (c) 2020 JPMS. All rights reserved
}

\begin{abstract}
Abstrak
Profesi perawat memiliki peranan penting dalam memberikan kualitas pelayanan kesehatan di rumah sakit, karena jenis pelayanan yang diberikannya dengan pendekatan biologis, psikologis, sosial, spiritual dan dilakukan dengan berkelanjutan. Kinerja tenaga perawat dipengaruhi oleh karakteristik perawat, kompetensi, motivasi dan beban kerja. Tujuan penelitian ini adalah untuk mengetahui analisis pengaruh kompetensi, motivasi dan beban kerja perawat pelaksana dengan kinerja perawat di ruang rawat inap RS Bhayangkara Tk II Medan. Penelitian menggunakan rancangan cross sectional dengan survey analytic. Sampel berjumlah 45 perawat pelaksana di ruang rawat inap yang diambil dengan menggunakan teknik total sampling. Data dikumpulkan dengan kuesioner dan lembar observasi, lalu dianalisis bivariat dengan uji chi-square dan multivariat dengan uji regresi logistik. Hasil penelitian menunjukkan ada hubungan bermakna antara kompetensi $(0,023)$, motivasi $(0,009)$ dan pendidikan $(0,043)$ dengan kinerja perawat. Sedangkan beban kerja $(0,136)$ tidak memiliki hubungan bermakna dengan kinerja perawat pelaksana di ruang rawat inap. Analisis multivariat menunjukkan aspek kompetensi merupakan variabel mempengaruhi kinerja dengan nilai Adjusted Odds Ratio (AOR) 12,953 dan bermakna secara statistik $(p=0,041)$. Nilai Adjusted Odds Ratio pada status pendidikan sebesar 3,663 dan bermakna secara statistik ( $p=0,027)$. Aspek motivasi merupakan variabel paling dominan mempengaruhi kinerja dengan nilai Adjusted Odds Ratio (AOR) 36,943 dan bermakna secara statistik ( $p=0,008)$. Penelitian ini menyimpulkan bahwa kinerja perawat sangat berhubungan dengan kompetensi dan motivasi kerja perawat, sehingga aspek-aspek yang dapat meningkatkan kompetensi dan motivasi kerja perlu dikelola dengan baik untuk mendapatkan hasil kinerja perawat yang baik.
\end{abstract}

Kata kunci: Kompetensi, motivasi, beban kerja, kinerja perawat

\begin{abstract}
The nursing profession has an important role in providing quality health services in hospitals, because the type of service it provides is based on a biological, psychological, social, spiritual approach and is carried out in a sustainable manner. The performance of nurses is influenced by the characteristics of nurses, competence, motivation and workload. The purpose of this study was to determine the analysis of the influence of competence, motivation and workload of nurses on the performance of nurses in the inpatient room at Bhayangkara Hospital Tk II Medan. This study used a cross sectional design with analytic survey. The total sample of 45 nurses in the inpatient room was taken using a total sampling technique. Data were collected using a questionnaire and observation sheet, then analyzed bivariately with the chi-square test and multivariate with logistic regression test. The results showed that there was a significant relationship between competence (0.023), motivation (0.009) and education (0.043) with the performance of nurses. Meanwhile, the workload (0.136) did not have a significant relationship with the performance of nurses in the inpatient room. Multivariate analysis showed that the competency aspect was a variable affecting performance with an Adjusted Odds Ratio (AOR) value of 12,953 and statistically significant $(p=0.041)$. The value of the Adjusted Odds Ratio for educational status was 3.663 and statistically significant $(p=0.027)$. The motivation aspect is the most dominant variable affecting performance with an Adjusted Odds Ratio (AOR) value of 36.943 and statistically significant $(p=0.008)$. This study concludes that the performance of nurses is closely related to the competence and work motivation of nurses, so that aspects that can increase competence and work motivation need to be managed properly to get good nurse performance results.
\end{abstract}


Keywords: competence, motivation, workload, nurse performance

\section{Pendahuluan}

Pelayanan keperawatan yang dilakukan kepada pasien di rumah sakit melalui asuhan keperawatan diharapkan menjadi berdaya guna dan berhasil guna. Kinerja perawat melalui pengelolaan asuhan keperawatan akan berhasil apabila memiliki tanggung jawab, mempunyai pengetahuan tentang manajemen keperawatan dan kemampuan memimpin orang lain di samping pengetahuan dan keterampilan klinis yang harus dikuasainya pula. Penurunan kinerja perawat dapat dipengaruhi oleh beberapa faktor terutama motivasi kerja dari perawat itu sendiri. Kondisi tersebut dapat dipengaruhi atas dua faktor antara lain faktor diri sendiri (internal) meliputi kepuasan dalam bekerja, penghargaan pribadi atau pengakuan, pekerjaan yang menantang, keinginan berprestasi, keinginan maju, dan keinginan untuk menikmati pekerjaan. Sedangkan faktor lingkungan (eksternal), meliputi hubungan dengan teman sejawat, suasana kerja, dan jaminan kerja. Maka bila hal tersebut kurang optimal dapat berdampak terhadap prestasi kerja (kinerja) yang akibatnya pada kepuasan kerja dan kepuasan pasien terhadap pelayanan kesehatan yang telah diterimanya. ${ }^{1}$

Faktor-faktor yang mempengaruhi kinerja suatu organisasi di antaranya adalah kemampuan, kemauan, energi, teknologi, kompensasi, kejelasan tujuan dan keamanan. Kinerja merupakan hasil nyata yang ditampilkan perawat dan merupakan prestasi kerja sesuai perannya di rumah sakit. Kinerja seseorang ditentukan oleh kemampuan dan motivasinya untuk melaksanakan pekerjaan. Kinerja perawat merupakan hasil kombinasi antara kemampuan, usaha dan kesempatan, dengan demikian kinerja dalah hasil kerja yang dicapai seseorang dalam melaksanakan tugasnya sesuai kecakapan, pengalaman dan kesungguhannya melaksanakan tugas-tugas. ${ }^{2}$

Berkembangnya kompetensi, motivasi dan beban kerja yang sesuai dengan tugas pokok dan fungsi, maka kualitas kinerja profesi keperawatan akan menjadi maksimal yang berfokus pada profesionalisme di dunia keperawatan. ${ }^{3}$ Kinerja atau keterampilan adalah sebagai hasil kerja atau prestasi kerja. Pada kenyataannya kinerja mempunyai makna yang lebih luas, bukan hanya sebagai hasil dari suatu pekerjaan, tetapi juga termasuk bagaimana proses pekerjaan berlangsung. Kinerja merupakan hasil pekerjaan yang mempunyai hubungan kuat dengan tujuan strategis organisasi, kepuasaan konsumen, serta berpengaruh terhadap kontribusi pada ekonomi. Kinerja adalah tentang apa yang dikerjakan dan bagaimana cara mengerjakannya. ${ }^{4}$

Pemerintah telah berupaya menciptakan pelayanan keperawatan yang baik sehingga dikeluarkan Surat Keputusan No. 129/Menkes/SK/II/2008 tentang Standar Asuhan Keperawatan, kemudian diperkuat dengan SK Dirjen Pelayanan Medik Depkes RI No.YM.000.03.2.6. 7367 Tahun 2008. PPNI mengeluarkan Surat Keputusan No. 03/DPP/SK/I/1996 tentang Standar Profesi Keperawatan, maka seluruh tenaga keperawatan di rumah sakit dalam memberikan asuhan keperawatan harus berpedoman pada standar asuhan keperawatan. Studi oleh Direktorat Keperawatan dan Keteknisian Medik Depkes RI bekerjasama dengan WHO tahun 2008 di 4 provinsi di Indonesia, yaitu DKI Jakarta, Sumatera Utara, Sulawesi Selatan dan Kalimantan Timur, menemukan $47,4 \%$ perawat belum memiliki uraian tugas secara tertulis, $70,9 \%$ perawat tidak pernah mengikuti pelatihan dalam 3 tahun terakhir, $39,8 \%$ perawat masih melaksanakan tugas non keperawatan, serta belum dikembangkan sistem monitoring dan evaluasi kinerja perawat. $^{5}$

Upaya untuk meningkatkan kinerja perawat melalui penerapan asuhan keperawatan yang maksimal, sangat dipengaruhi oleh sumber daya manusia khususnya tingkat kompetensi perawat, motivasi dalam bekerja dan juga beban pekerjaan yang dipikulnya. Kompetensi terdiri dari tiga komponen, yakni pengetahuan, sikap dan keterampilan. Motivasi adalah dorongan yang timbul dari penilaian perawat terhadap organisasi dalam pemenuhan kebutuhan. Indikator yang diukur dalam motivasi adalah afiliasi, reward, dan punishment. Berdasarkan Undang-Undang Kesehatan No. 39 Tahun 2009, disebutkan bahwa beban 
kerja merupakan besaran pekerjaan yang harus ditanggung dari jabatan atau unit organisasi dan merupakan hasil kali antara jumlah pekerjaan dengan waktu. ${ }^{6}$

Rumah Sakit Bhayangkara Tingkat II Medan adalah salah satu rumah sakit tingkat II yang dimiliki Polri selain di Bandung, Surabaya dan Makasar yang merupakan salah satu provider pelayanan kesehatan program Jaminan Kesehatan Nasional di Kota Medan. Ditinjau dari kategori organisasi rumah sakit Depkes, tingkatan rumah sakit ini sebenarnya adalah setara kelas B, yaitu rumah sakit yang mempunyai pelayanan dengan minimal sebelas spesialis dan subspesialis terdaftar.

Berdasarkan hasil survei awal yang dilakukan tanggal 25 Juni 2018 didapatkan data profil efesiensi Rumah Sakit Bhayangkara Tk. II Medan. Data rekam medik Rumah Sakit Bhayangkara Tingkat II Medan Tahun 2017 menunjukkan nilai Bed Occupancy Rate (BOR) yakni $57 \%$. Terjadi peningkatan dari nilai BOR di Rumah Sakit Bhayangkara Tingkat II Medan yakni pada tahun 2016 yaitu 55\% dan BOR tahun 2015 yaitu 51\%. BOR Rumah Sakit Bhayangkara masih rendah sesuai dengan nilai parameter BOR yang ideal menurut Depkes RI (2005) yaitu $60-80 \%$. Tenaga fungsional perawatan di unit rawat inap berjumlah 45 perawat dan jumlah tempat tidur pasien 105 tempat tidur. Semua ruangan di RS. Bhayangkara Tk. II Medan sudah menerapkan asuhan keperawatan yaitu sebanyak 5 ruangan. Ruangan tersebut yaitu Ruang Teratai (VIP dan super VIP), Anggrek (Kelas I, II), Flamboyan (Anak dan Obgyn), Mawar (Kelas III), Tulip (pasien tahanan). Jumlah dari perawat di semua ruangan rawat inap adalah 45 perawat dari total 99 perawat yang bertugas di RS. Bhayangkara Tk. II Medan.

Dari data rekam medik Rumah Sakit Bhayangkara Tk. II Medan terjadi peningkatan pasien rawat inap pada bulan Januari-Juni 2018 tanpa disertai dengan penambahan jumlah perawat. Perbandingan jumlah perawat dengan pasien yang dirawat di seluruh ruangan rawat inap adalah rata-rata 45 perawat berbanding 161 pasien, dengan rata-rata jumlah perawat jaga setiap shift setiap ruangan jaga 3 perawat merawat 53 pasien yang mana hal tersebut menunjukkan beban kerja perawat yang tinggi. Berdasarkan hasil survey terhadap
10 perawat shift pagi ditemukan bahwa 2 kompetensinya kurang, 3 motivasinya kurang, dan 5 beban kerjanya tinggi. Kegiatan asuhan keperawatan belum optimal dilakukan, hal ini dapat dilihat dari banyaknya kegiatan yang belum terlaksana di semua ruangan rawat inap. Penelitian ini bertujuan untuk menganalisis pengaruh kompetensi, motivasi dan beban kerja perawat pelaksana dengan kinerja perawat di Ruang Rawat Inap Rumah Sakit Bhayangkara Tingkat II Medan.

\section{Metode Penelitian}

Penelitian survei analtik dengan pendekatan cross-sectional ini dilakukan di ruangan rawat inap Rumah Sakit Bhayangkara tingkat II Medan pada bulan Februari - Oktober 2018. Populasi dalam penelitian ini perawat pelaksana di Ruang Rawat Inap Rumah Sakit Bhayangkara tingkat II Medan sebanyak 45 orang dan seluruhnya dijadikan sampel penelitian. Pengumpulan dilakukan dengan menyebarkan kuesioner kepada responden, penelusuran dokumen/laporan dan studi kepustakaan. Analisis data menggunakan uji chi square dan regresi logistik.

\section{Hasil}

Perawat pada penelitian ini mayoritas berada pada kelompok umur $26-35$ tahun 24 responden (53.3\%) dan selebihnya umur 46-55 tahun 3 responden (6.7\%). Perawat mayoritas perempuan 38 responden (84.4\%) dan laki-laki 7 responden (15.6\%). Perawat mayoritas tamatan pendidikan D-III keperawatan 31 responden $(68.9 \%)$ dan tamatan pendidikan Spk/Spr 2 responden (4.4\%). Perawat mayoritas lama kerja kurang dari 10 Tahun 33 responden (73.3\%) dan lebih dari 10 tahun 12 responden (26.7\%). Perawat mayoritas sudah kawin 29 responden $(64.4 \%)$ dan belum kawin 16 responden (35.6\%). Perawat memiliki jumlah anak dengan proporsi sama dengan memiliki anak satu sampai 2 yaitu 21 orang (46.7\%) dan memiliki anak lebih dari dua 3 responden $(6.7 \%)$. Perawat mayoritas berstatus pegawai kontrak 30 orang $(66.7 \%)$ dan selebihnya berstatus PNS (Gol II dan III) 3 responden (6.7\%).

Mayoritas perawat memiliki jarak tempat tinggal ke rumah sakit kurang dari $5 \mathrm{Km} 25$ responden (55.6\%) dan lebih dari $5 \mathrm{Km} 20$ 
responden (44.4\%). Perawat mayoritas bekerja pada ruangan Anggrek 11 responden (24.4\%) dan minoritas di ruangan Tulip 7 responden (15.6\%).
Variabel independen penelitian yang diteliti terdiri dari kompetensi, motivasi, beban kerja dan variabel dependen yaitu kinerja perawat.

Tabel 1. Karakteristik responden $(n=45)$

\begin{tabular}{lcc}
\hline & Jumlah $(\mathbf{n})$ & Persentase (\%) \\
\hline $\begin{array}{l}\text { Kompetensi } \\
\quad \text { Kurang }\end{array}$ & 8 & 17,8 \\
$\quad$ Baik & 37 & 82,2 \\
$\begin{array}{l}\text { Motivasi } \\
\quad \text { Kurang }\end{array}$ & & \\
$\quad$ Baik & 12 & 26,7 \\
Beban Kerja & 33 & 73,3 \\
$\quad$ Tidak berat & & \\
$\quad$ Berat & 8 & 17,8 \\
Kinerja & 37 & 82,2 \\
$\quad$ Kurang & & \\
$\quad$ Baik & 23 & 51,1 \\
\hline
\end{tabular}

Distribusi kategori responden variabel kompetensi terbanyak adalah baik sebesar 37 orang $(82,2 \%)$. Distribusi responden terbanyak untuk variabel motivasi adalah dalam kategori baik yaitu 33 orang $(73,3 \%)$, dan berdasarkan distribusi frekuensi variabel beban kerja yang terbanyak adalah dalam kategori berat sebesar 37 orang $(82,2 \%)$, dan kategori tidak berat sebanyak 8 orang $(17,8 \%)$. Dari hasil penelitian dapat diketahui deskripsi responden untuk variabel kinerja perawat terbanyak adalah baik sebanyak 22 orang $(48,9 \%)$ dan kategori kurang sebanyak 23 orang $(51,1 \%)$.

Distribusi responden untuk variabel kompetensi terdiri dari tiga indikator yaitu pengetahuan, keterampilan dan sikap profesional. Indikator pengetahuan yang terbanyak adalah baik sebanyak 39 orang $(86,7 \%)$. Indikator Ketrampilan yang terbanyak adalah baik sebanyak 39 orang $(86,7 \%)$, dan indikator sikap profesional yang terbanyak adalah baik (39 orang). Distribusi responden terbanyak untuk indikator variabel motivasi terdiri dari tiga indikator yaitu afiliasi, reward dan punishment. Indikator afiliasi yang terbanyak adalah baik sebanyak 38 orang $(84,4 \%)$. Indikator reward yang terbanyak adalah baik sebanyak 29 orang $(64,4 \%)$, dan indikator punishment yang terbanyak adalah baik, sebanyak 35 orang (77,8\%).

Distribusi frekuensi indikator variabel beban kerja terdiri dari tiga indikator/aspek yaitu aspek fisik, psikologis dan waktu kerja. Indikator aspek fisik yang terbanyak adalah berat sebanyak 37 orang $(82,2 \%)$. Indikator aspek psikologis yang terbanyak adalah berat sebanyak 40 orang $(88,9 \%)$, dan indikator waktu kerja yang terbanyak adalah berat, sebanyak 24 orang (53.3\%). Deskripsi responden untuk variabel tingkat kinerja terdiri dari lima indikator yaitu pengkajian, diagnosa keperawatan, perencanaan, implementasi keperawatan, evaluasi. Indikator pengkajian yang terbanyak adalah baik sebesar 39 orang $(86,7 \%)$. Diagnosa keperawatan yang terbanyak adalah kurang sebesar 31 orang (68.9\%). Perencanaan yang terbanyak adalah kurang sebesar 28 orang (62.2\%). Implementasi keperawatan yang terbanyak adalah kurang sebanyak 30 orang (66.7\%). Evaluasi yang terbanyak adalah kurang sebesar 35 orang (77,8\%).

Dari hasil uji statistik Chi-square diketahui bahwa pendidikan $(0,043)$, kompetensi $(0,023)$ dan motivasi $(0,009)$ berhubungan dengan kinerja perawat. Namun beban kerja tidak berhubungan dan nilai probabilitas 0,136 .

Variabel kompetensi dengan pengetahuan yang baik menunjukkan kinerja yang baik sebesar 20 orang $(44,4 \%)$, dengan nilai OR 2,1 dan $p=0,413$ yang berarti pengetahuan yang baik tidak memiliki makna dalam melakukan kinerja yang baik. Indikator ketrampilan menunjukkan bahwa perawat yang keteram- 
pilannya baik tidak berpotensi melakukan kinerja yang baik sebesar 5,9 kali dengan nilai $p=0,090$. Berdasarkan nilai sikap, sikap yang baik menunjukkan kinerja yang baik sebanyak 20 orang $(44,4 \%)$, sikap yang baik tidak memiliki makna melakukan kinerja yang baik sebesar 2,1 dan nilai $p=0,413$.

Variabel motivasi dengan indikator afiliasi yang baik menunjukkan kinerja baik sebesar 20 orang $(44,4 \%)$, dengan nilai OR 2,7 dan $p=0,242$ yang berarti bahwa afiliasi yang baik tidak memiliki makna melakukan kinerja baik. Indikator reward yang baik menunjukkan kinerja baik sebesar 18 orang $(40,0 \%)$, dengan nilai OR 4,9 dan $\mathrm{p}=0,017$ yang berarti reward yang baik berpotensi melakukan kinerja baik sebanyak 4,9 kali dibandingkan perawat yang reward-nya kurang. Indikator punishment menunjukkan perawat yang punishment-nya baik sebanyak 19 orang $(42,2 \%)$ dengan OR 2,8 dan nilai $p=0,175$, tidak berpotensi melakukan kinerja baik.

Variabel beban kerja, sebagian besar responden menyebutkan aspek fisik berat tetapi menunjukkan kinerja yang baik sebesar 20 orang $(44,4 \%)$, dengan nilai OR 3,5 dan $p=0,136$ yang berarti aspek fisik tidak berpengaruh secara signifikan terhadap kinerja perawat. Indikator aspek psikologis berat menunjukkan kinerja yang baik sebesar 20 orang $(44,4 \%)$ dengan nilai $O R$ 1,5 dan nilai $p=0,673$. Dan indikator waktu kerja yang berat dengan kinerja yang baik sebanyak 14 orang $(31,1 \%)$, dengan OR 2,3 dan nilai $p=0,175$.

Pada tahap selanjutnya adalah analisis multivariat menggunakan uji regresi logistik berganda. Hubungan kompetensi dengan adjusted odd ratio sebesar 12,953 artinya peluang untuk memberi kinerja baik pada kompetensi baik sebesar 12,953 kali daripada kompetensi kurang dan bermakna secara statistik dengan nilai $\mathrm{p}=0,041,95 \% \mathrm{Cl}$ : 1,109-151,334. Hubungan motivasi dengan adjusted odd ratio sebesar 36,943 artinya peluang untuk memberikan kinerja baik pada motivasi yang baik sebesar 36,943 kali daripada motivasi kurang. Hubungan ini bermakna secara statistik dengan nilai $\mathrm{p}=0,010,95 \% \mathrm{Cl}: 2,558-533,566$. Hubungan pendidikan dengan adjusted odd ratio sebesar 3,663 namun hubungan ini bermakna secara statistik dengan nilai $p=0,027$, 95\%Cl:1,155-11,617.

Tabel 2. Analisis multivariat

\begin{tabular}{ccccc}
\hline \multirow{2}{*}{ Variabel } & \multirow{2}{*}{ OR } & \multicolumn{2}{c}{$\mathbf{9 5 \%}$ Confident Interval } & \multirow{2}{*}{$\mathbf{p}$} \\
\cline { 3 - 4 } & & Batas Bawah & Batas Atas & \\
\hline Kompetensi & 12,953 & 1,109 & 151,334 & 0,041 \\
Motivasi & 36,943 & 2,558 & 533,566 & 0,008 \\
Pendidikan & 3,663 & 1,155 & 11,617 & 0,027 \\
\hline
\end{tabular}

\section{Pembahasan}

Kinerja adalah penampilan hasil kerja pegawai baik secara kuantitas maupun kualitas. ${ }^{8}$ Kinerja adalah apa yang dapat dikerjakan seseorang sesuai dengan bidang tugas dan fungsinya yang merupakan pekerjaan gabungan dari karakteristik pribadi dan pengorganisasian seseorang. ${ }^{1}$ Pada penelitian ini kinerja perawat diperoleh dengan cara pengamatan dokumentasi asuhan keperawatan yang dikerjakan perawat. Hasil penelitian yang dilakukan terhadap kinerja perawat, menunjukkan bahwa perawat di ruang rawat inap Rumah Sakit Bhayangkara Tingkat II Medan, sebagian besar atau $51,1 \%$ responden memiliki kinerja yang kurang dan 48,9\% responden memiliki kinerja yang baik. Penilaian kinerja perawat dalam penelitian ini dilakukan melalui pelaksanaan asuhan keperawatan yang meliputi pengkajian, diagnosa, perencanaan, pelaksanaan dan evaluasi.

Hasil pengamatan menggunakan lembar observasi yang dilakukan oleh peneliti dan kepala ruangan menunjukkan bahwa perawat sudah melakukan pengkajian, merumuskan diagnosa, menyusun perencanaan, melakukan intervensi dan evaluasi sesuai dengan standar asuhan keperawatan (SAK) yang ada di Rumah Sakit Bhayangkara Medan. Hasil analisis peneliti berdasarkan hasil observasi di ruangan rawat inap Rumah Sakit Bhayangkara Tingkat II Medan didapatkan perawat tidak rutin melakukan pengkajian ulang pada pasien sehingga diagnosis terbaru tidak dapat dievaluasi. Pada tahap perencanaan sering bersifat rutin sehingga pelaksanaan tindakan tidak sesuai 
dengan kebutuhan pasien. Kolaborasi bersama tim kesehatan lain tidak konsisten dapat dilakukan, hal ini terjadi karena dokter ruangan tidak selalu berjaga di ruangannya dan visite di ruangan biasanya hanya dilakukan pada pagi hari dan tidak setiap hari, tentu ini menjadi suatu kendala pada saat perawat dinas sore atau malam hari. Pelaksanaan implementasi perawatan asuhan keperawatan masih bersifat rutin sehingga tidak sesuai prioritas masalah dan kebutuhan pasien.

Evaluasi pada perawat hanya menggunakan evaluasi formatif yaitu evaluasi yang dilakukan setelah dilakukan intervensi keperawatan tertentu, namun jarang melakukan evaluasi sumatif sehingga perkembangan atau kemajuan masalah keperawatan jiwa pasien tidak dapat di follow-up sejauh mana keberhasilan asuhan keperawatan yang dilakukan perawat kepada pasien. Hal ini sangat prinsip sehingga bila tidak dilakukan akan mempengaruhi kinerja perawat secara keseluruhan dalam merawat pasien dengan gangguan jiwa.

Kompetensi merupakan kemampuan melaksanakan pekerjaan atau tugas yang didasari keterampilan maupun pengetahuan dan didukung oleh sikap kerja yang ditetapkan oleh pekerjaan. Kompetensi menunjukkan pengetahuan, ketrampilan dan sikap tertentu dari suatu profesi dalam ciri keahlian tertentu, yang menjadi ciri dari seorang profesional. ${ }^{4}$ Kompetensi merupakan kemampuan intelektual, fisik dan hubungan antar manusia yang mendasari perawat dalam melaksanakan asuhan keperawatan. Kompetensi diukur dengan sub variabel intelektual, fisik dan human relation. Faktorfaktor dari kemampuan ada dua, yaitu: (1) Kemampuan fisik yakni kemampuan dalam beraktivitas menurut kondisi stamina, kekuatan dan karakteristik biologis, (2) Kemampuan intelektual yaitu kemampuan dalam kegiatan yang berhubungan dengan aktivitas mental. ${ }^{7}$

Hasil analisis univariat menunjukkan bahwa distribusi responden menyatakan sebagian besar dengan kategori baik berjumlah 37 orang $(17,8 \%)$ dan sebagaian kecil 8 orang $(17,8 \%)$ dengan kategori kurang. Uji bivariat pada hubungan kompetensi dengan kinerja perawat di RS Bhayangkara Tk II Medan menunjukkan menunjukkan nilai Odds Ratio sebesar 9,2 sedangkan nilai $p=0,023$. Dapat disimpulkan bahwa kompetensi berpengaruh secara parsial terhadap kinerja perawat di ruang rawat inap Rumah Sakit Bhayangkara Tk II Medan. Semakin baik kompetensi perawat semakin baik pula kinerjanya. Hasil tersebut menunjukkan kompetensi baik berpotensi memberikan kinerja yang baik sebesar 9,2 kali dibandingkan dengan perawat yang kompetensinya kurang dan memiliki pengaruh yang signifikan secara parsial terhadap kinerja perawat. Namun hal tersebut tidak didukung oleh pengetahuan, keterampilan dan sikap.

Penelitian Budiawan (2015) menemukan pengaruh positif dan signifikan antara kompetensi profesional dengan kinerja perawat ruang rawat inap Rumah Sakit Jiwa Bali yang ditunjukkan oleh nilai $p=0,001$ yang artinya adalah bahwa kompetensi yang baik akan berpeluang memberikan kinerja yang baik. ${ }^{8}$

Aspek pengetahuan menunjukkan bahwa pengetahuan yang baik berpotensi paling tinggi menghasilkan kinerja yang baik, yakni sebesar $79,6 \%$ (86 orang). Hal ini ditunjang dari indikator pengetahuan, yakni intelektual, pengetahuan dan inisiatif menunjukkan hasil yang baik. Aspek ketrampilan menunjukkan sebanyak $82,1 \%$ (89 orang) yang memiliki ketrampilan baik menunjukkan kinerja baik, meliputi indikator fisik, kuantitas kerja dan kualitas kerja yang menunjukkan nilai baik. Sikap yang baik juga menunjukkan hasil paling tinggi yang mana sebanyak $84,5 \%$ (90 orang) berkinerja baik, meliputi human relation, kerjasama dan integritas pribadi menunjukkan nilai yang baik. ${ }^{8}$

Hasil tersebut berbeda dengan penelitian ini yang mana semua indikator aspek pengetahuan, keterampilan dan sikap tidak menunjukkan hubungan yang signifikan terhadap kinerja perawat. Pengetahuan yang baik tidak berpotensi menghasilkan kinerja yang baik, yakni sebesar 20 orang $(44,4 \%)$. Sebanyak 21 orang yang memiliki keterampilan baik menunjukkan kinerja baik, namun tidak memiliki hubungan yang signifikan. Sikap yang baik juga menunjukkan yang mana sebanyak 20 orang $(44,4 \%)$ berkinerja baik, namun tidak menunjukkan nilai yang berhubungan dengan kinerja. Hal ini juga ditunjang dari karakteristik responden sebagian besar berpendidikan D3 sebanyak 23 orang $(51,1 \%)$, SPK/SPR sebanyak 10 orang $(22,2 \%)$, D4 sebanyak 6 orang $(13,3 \%)$, serta S1 yakni sebanyak 6 orang 
(13,3\%), sehingga berdampak baik terhadap peningkatan pengetahuan perawat dan berhubungan dengan kinerja yang baik.

Motivasi adalah keinginan yang terdapat pada diri seorang individu yang merangsangnya untuk melakukan tindakan. ${ }^{9}$ Sedangkan motivasi diartikan sebagai kebutuhan psikologis yang telah memiliki motivasi kerja corak atau arah yang ada dalam diri individu yang harus dipenuhi agar kehidupan kejiwaannya terpelihara, yaitu senantiasa berada dalam keadaan seimbang yang nyaman (homeostatis, equilibrium). ${ }^{10}$ Motivasi mengupayakan cara mengoptimalkan potensi pegawai untuk dapat bekerja dengan baik, mau bekerjasama untuk mendorong peningkatan kinerja pegawai, sehingga berhasil mencapai dan mewujudkan tujuan yang telah ditentukan. ${ }^{11}$ Kuat dan lemahnya motivasi kerja seorang tenaga kerja ikut menentukan besar kecilnya prestasinya. Motivasi kerja yang semakin tinggi menjadikan seseorang mempunyai semangat yang tinggi untuk memberikan pelayanan yang terbaik demi mencapai kinerja yang maksimal.

Motivasi merupakan dorongan yang timbul dari penilaian perawat terhadap organisasi dalam pemenuhan kebutuhan. Indikator yang diukur dalam variabel motivasi ini adalah motivasi afiliasi, reward dan punishment. Distribusi responden terbanyak untuk variabel motivasi adalah dalam kategori baik yaitu 33 orang $(73,3 \%)$ dan kategori kurang sebanyak 12 orang $(26,7 \%)$. Hasil analisis data secara statistik menunjukkan hasil uji koefisien regresi secara parsial dengan nilai Odds Ratio 7,6 sedangkan nilai signifikansinya adalah 0,009, yang berarti bahwa perawat yang tingkat motivasinya baik akan berpotensi memberikan kinerja yang baik sebesar 7,6 kali dibandingkan dengan yang tingkat motivasinya kurang. Berdasarkan data tersebut maka dapat disimpulkan bahwa motivasi berpengaruh secara parsial terhadap kinerja perawat di ruang rawat inap Rumah Sakit Bhayangkara Tk II Medan. Hal ini menunjukkan semakin baik motivasi kerja perawat semakin baik pula kinerjanya.

Hasil penelitian ini sesuai dengan penelitian Jimat (2013) didapatkan hasil motivasi, kompetensi serta lingkungan kerja mempunyai pengaruh terhadap kinerja perawat di RSUD Bangli, yang ditunjukkan oleh hasil uji $\mathrm{F}$ hitung sebesar 67,120 dengan signifikansi 0,000. Sedangkan secara parsial ada pengaruh signifikan antara motivasi terhadap kinerja perawat dengan hasil uji t hitung sebesar 9,710 dengan signifikansi sebesar $0,023 .{ }^{12}$

Penelitian Mudayana (2010) mendapatkan hasil motivasi berpengaruh signifikan terhadap kinerja karyawan di RS Nur Hidayat Bantul $(p=0,000) .{ }^{13}$ Penelitian Setyaningsih dan Hartanto (2010) menunjukkan motivasi berpengaruh secara signifikan terhadap kinerja pegawai di Kecamatan Jumanto Kabupaten Karanganyar $(t=2,150 ; p=0,041) .{ }^{14}$

Indikator afiliasi yang baik tidak berpotensi menghasilkan kinerja yang baik, yakni sebesar 20 orang $(44,4 \%)$ dengan OR 2,8 dan nilai $p=0,242$. Hal ini berbeda dengan indikator reward menunjukkan sebanyak 18 orang $(40,0 \%)$ dengan OR 4,9 dan nilai $p=0,017$ yang memiliki reward baik menunjukkan kinerja baik. Indikator punishment yang baik juga tidak menunjukkan hasil yang berhubungan baik dengan kinerja, yang mana sebanyak 19 orang $(42,2 \%)$ berkinerja baik dengan OR 2,8 dan nilai $p=0,175$, sehingga secara keseluruhan motivasi hanya indikator reward yang baik berhubungan signifikan dengan kinerja perawat.

Beban kerja merupakan jumlah rata-rata kegiatan kerja pada waktu tertentu, yang terdiri dari beban kerja fisik, beban kerja psikologis serta waktu kerja. ${ }^{15}$ Beban kerja adalah besaran pekerjaan yang harus dipikul oleh suatu jabatan dalam suatu unit organisasi dan merupakan hasil kali antara jumlah pekerjaan dengan waktu. Untuk itu perlu dilakukan upaya penyerasian antara kapasitas kerja, beban kerja dan lingkungan kerja agar diperoleh produktivitas kerja yang optimal. ${ }^{16}$

Beban kerja adalah upaya merinci komponen dan target volume pekerjaan dalam satuan waktu dan satuan hasil tertentu. Kinerja adalah penampilan hasil kerja personel baik secara kuantitas maupun kualitas dalam suatu organisasi. Kinerja tenaga perawat dipengaruhi oleh beberapa faktor, salah satunya adalah beban kerja. Beban kerja berkaitan erat dengan kinerja tenaga kesehatan di mana 53,2\% waktu yang benar-benar produktif yang digunakan pelayanan kesehatan langsung dan sisanya $39,9 \%$ digunakan untuk kegiatan penunjang. ${ }^{17}$

Menurut Kurniadi (2013), yang mempengaruhi beban kerja perawat adalah kondisi 
pasien yang selalu berubah, jumlah rata-rata jam perawatan yang dibutuhkan untuk memberikan pelayanan langsung pada pasien dan dokumentasi asuhan keperawatan serta banyaknya tugas tambahan yang harus dikerjakan oleh seorang perawat sehingga dapat mempengaruhi kinerja perawat tersebut. $^{7}$

Beban kerja menunjukkan bahwa indikator aspek fisik yang berat berpotensi paling tinggi menghasilkan kinerja yang baik, yakni sebesar 20 orang $(44,4 \%)$. Hal ini ditunjang dari indikator aspek psikologis menunjukkan sebanyak 20 orang $(44,4 \%)$ yang memiliki aspek psikologis berat menunjukkan kinerja yang baik. Indikator pada aspek waktu kerja yang berat juga menunjukkan hasil paling tinggi yang mana sebanyak 14 orang $(31,1 \%)$ berkinerja baik.

Berdasarkan hasil penelitian didapatkan bahwa sebanyak 37 orang $(82,2 \%)$ responden mengatakan beban kerja mereka berat dan sebanyak 8 orang $(17,8 \%)$ mengatakan beban kerja mereka tidak berat. Secara statistik hasil penelitian didapatkan 2 orang $(4,4 \%)$ responden yang memiliki beban kerja tidak berat memiliki kinerja baik, 20 orang $(44,4 \%)$ responden yang memiliki beban kerja berat memiliki kinerja baik. Hasil analisis bivariat dengan Chi-square didapat $p$ value sebesar 0,136 ini menunjukkan tidak ada hubungan yang bermakna antara beban kerja dengan kinerja perawat.

Hal ini dipengaruhi dari jumlah perawat di tiap-tiap ruangan masih kurang memadai, setiap perawat melaksanakan tugas belum sesuai tupoksinya, lingkungan psikologis yang kurang nyaman, selain melakukan tugas keperawatan, perawat sering melaksanakan tugastugas tambahan yang ditugaskan atasan.

Jumlah pasien yang dirawat banyak dengan karakteristik pasien yang berbeda-beda mempengaruhi beban kerja perawat yang tentunya kesemua hal tersebut menambah beban dari pekerjaan perawat di ruangan. Selain hal tersebut ada juga beberapa hal yang dapat mengurangi beban kerja perawat, sehingga meskipun pekerjaan dirasakan berat tetapi tidak berpengaruh terhadap kinerjanya, dan masih dapat melaksanakan kinerja dengan baik, seperti hubungan kerja antar perawat terjalin dengan baik, waktu kerja yang tidak memberatkan perawat, penjadwalan jaga perawat yang dapat menyesuaikan dengan kegiatan informal dan keseharian perawat, proses pertukaran jadwal antar perawat bisa dilakukan dalam aktivitas jaga setiap harinya. Beberapa kondisi tersebut menjadikan beban kerja perawat tidak berpengaruh secara signifikan dengan kinerja perawat di ruang rawat inap RS Bhayangkara Tk II Medan.

Hasil penelitian ini berbeda dengan penelitian Nurnaningsih (2012) mengatakan bahwa ada hubungan yang bermakna antara beban kerja terhadap kinerja perawat pelaksana dalam pemberian pelayanan kesehatan di ruang rawat inap Rumah Sakit Islam Faisal Makassar. ${ }^{18}$ Penelitian oleh Minarsih (2011) menunjukkan bahwa sebanyak $62,7 \%$ perawat menyatakan memiliki beban kerja tinggi, dan $37,3 \%$ menyatakan beban kerja sedang. Dapat disimpulkan bahwa ada hubungan antara beban kerja perawat dengan produktivitas kerja perawat di IRNA non bedah RSUP Dr. M. Djamil Padang. ${ }^{19}$

Hasil penelitian Sutarto (2016) di RSUD Dr. Soediran Mangun Sumarso Perawat dengan beban kerja sedang rata-rata memiliki skor kinerja lebih tinggi daripada beban kerja ringan, dan secara statistik signifikan $(b=3.33$; $\mathrm{Cl} 95 \%=1.16$ hingga 5.49; $p=0.003)$. Perawat dengan beban kerja berat rata-rata memiliki skor kinerja lebih tinggi daripada beban kerja ringan, tetapi perbedaan tersebut secara statistik tidak signifikan $(b=0.81 ; C l 95 \%=-1.37$ hingga 2.99; $p=0.459) .{ }^{20}$

Perawat bertugas merawat pasien dalam waktu 24 jam dengan menerapkan asuhan keperawatan, sejak pasien masuk rumah sakit sampai keluar rumah sakit. Adapun beberapa faktor yang mempengaruhi beban kerja seorang perawat yaitu faktor internal dan faktor eksternal. Faktor internal berasal dari pengaruh tubuh sendiri, meliputi faktor biologis dan faktor psikologis. Sedangkan faktor eksternal merupakan faktor yang berasal dari luar biologis perawat. Salah satu faktor internal yang sangat mempengaruhi besarnya beban kerja perawat adalah faktor psikologis. Pelaksanaan kerja perawat sebagai profesi yang mengemban tanggung jawab yang besar, menuntut kepada anggotanya untuk memiliki sikap, pengetahuan dan keterampilan diterapkan pada asuhan keperawatan sesuai dengan 
kode etik profesi. ${ }^{21}$

Beban kerja menunjukkan bahwa indikator aspek fisik yang berat berpotensi paling tinggi menghasilkan kinerja yang baik, yakni sebesar 20 orang $(44,4 \%)$. Hal ini ditunjang dari indikator aspek psikologis menunjukkan sebanyak 20 orang $(44,4 \%)$ yang memiliki aspek psikologis berat menunjukkan kinerja yang baik. Indikator pada aspek waktu kerja yang berat juga menunjukkan hasil paling tinggi yang mana sebanyak 14 orang $(31,1 \%)$ berkinerja baik.

Hasil uji statistik menunjukkan bahwa aspek motivasi merupakan variabel yang memiliki nilai Odds Ratio (OR) terbesar yaitu 36,94 . Jadi dapat disimpulkan motivasi yang paling dominan mempengaruhi kinerja perawat di Ruang Rawat Inap Rumah Sakit Bhayangkara Tk II Medan.

Motivasi yang kurang menyebabkan perawat kurang memiliki afiliasi, reward dan punishment dalam bekerja sehingga tidak dapat menerapkan teori dengan baik. Efek yang paling sederhana dan jelas dari kurangnya motivasi adalah tidak bisa melaksanakan tugas pokok dan fungsi, karena tidak memahami ruang lingkup tugas yang harus dilaksanakan, karena tanpa dorongan semangat dari dalam diri seorang perawat, maka hasil kerja yang ditunjukkan tidak akan maksimal yang mengakibatkan menurunnya kinerja perawat dalam memberikan asuhan keperawatan, kinerja perawat timbul sebagai respon efektif atau emosional terhadap tugas pekerjaan yang dilakukan perawat. Jadi aspek afiliasi, reward dan punishment memegang peranan sangat penting dalam mempengaruhi kinerja perawat.

Pemberian penghargaan seperti insentif merupakan faktor penting untuk dapat menarik, memelihara maupun mempertahankan tenaga kerja bagi kepentingan organisasi. Dengan demikian, baiknya kinerjanya perawat dapat dikaitkan dengan besarnya tindakan pemberian insentif yang diberikan, karena itu tindakan ini memegang peranan penting dalam melaksanakan tugas dan tanggung jawabnya sehinnga adanya motivasi untuk meningkatkan efisiensi, efektifitas dan kinerja perawat yang dapat meningkatkan mutu pelayanan kepada pasien. Banyaknya tugas tambahan di luar tugas pokok dan fungsi perawat mempengaruhi pelaksanaan tugas pokok perawat yaitu memberikan asuhan keperawatan, sehingga dapat mengganggu penampilan kerja dari perawat tersebut dan dapat menurunkan kinerja perawat.

Keterbatasan dalam penelitian ini adalah dalam pengumpulan data menggunakan kuesioner dan lembar observasi yang mengukur aspek kompetensi, motivasi dan beban kerja dari sudut pandang persepsi responden petugas, belum sepenuhnya dilakukan crosscheck kepada pelaksanaan kinerja dan lembar dokumentasi. Pengumpulan data terkait kompetensi, motivasi, beban kerja dan kinerja yang menilai tentang diri sendiri juga mengalami keterbatasan yaitu terjadi social desirable bias yaitu kecenderungan seseorang untuk menjawab pertanyaan sedemikian rupa sehingga membuat dirinya terlihat positif sesuai dengan norma yang standar yang seharusnya.

\section{Kesimpulan}

Penelitian ini menyimpulkan adanya hubungan antara pendidikan $(0,043)$, kompetensi $(0,023)$ dan motivasi $(0,009)$ dengan kinerja perawat di Ruang Rawat Inap Rumah Sakit Bhayangkara Tk II Medan. Sedangkan beban kerja tidak berhubungan $(0,136)$ secara statistik. Aspek motivasi merupakan variabel yang paling dominan mempengaruhi kinerja perawat dengan nilai Odds Ratio (OR) terbesar yaitu 36,94. Disarankan untuk memberikan reward bagi perawat agar dapat meningkatkan kinerja perawat dalam melaksanakan asuhan keperawatan.

\section{Referensi}

1. Mangkunegara AAAP. Evaluasi Kinerja Sumber Daya Manusia. Refikaditama Bandung. 2008.

2. Pasolong H. Teori Administrasi Publik. Alfabeta. Bandung. 2011.

3. Notoatmodjo S. Metodologi Penelitian Kesehatan. Rineka Cipta. Jakarta. 2010.

4. Wibowo. Manajemen Kinerja. Raja Grafindo Persada. Jakarta. 2012.

5. Depkes. Standar Pelayanan Rumah Sakit. Jakarta. 2013.

6. Pemerintah Republik Indonesia. UndangUndang Kesehatan No 39 Tahun 2009. Jakarta. 2009. 
7. Kurniadi A. Manajemen Keperawatan dan Prospektifnya: Teori, Konsep dan Aplikasi. Badan Penerbit FKUI. Jakarta. 2013.

8. Budiawan N. Kompetensi, motivasi, beban kerja perawat pelaksana dengan kinerja perawat di ruangan rawat inap Rumah sakit Jiwa Propinsi Bali. Tesis. Universitas Udayana. Denpasar. 2015.

9. Andayani SA. Hubungan Kompensasi, Kompetensi dan Motivasi dengan Kinerja Dosen di STIKES Nurul Jadid Paiton Probolinggo. Tesis. Universitas Sebelas Maret. Surakarta. 2014.

10. Tawale B, Nurcholis. Hubungan antara Motivasi Kerja Perawat dengan Kecenderungan Mengalami Burnout pada Perawat di RSUD Serui Papua. Jurnal Insan. 13 (2): 74-84. 2011.

11. Toode K. Nurse's Work Motivation. Dissertation. University of Tampere. Finlandia. 2015.

12. Jimat A. Pengaruh Motivasi, Kompetensi dan Lingkungan Kerja Terhadap Kinerja Perawat di Ruang Rawat Inap Kelas III Rumah Sakit Umum Bangli. Tesis. Universitas Mahasaraswati. Denpasar. 2013.

13. Mudayana AA. Pengaruh Motivasi dan Beban Kerja Terhadap Kinerja Karyawan di Rumah Sakit Nur Hidayah Bantul. KESMAS 4(2): 76-143. 2010.

14. Setianingsih dan Hartanto. Pengaruh Kepemimpinan, Motivasi, Komunikasi, dan Lingkungan Kerja Terhadap Kinerja Pegawai Kecamatan Jumantono Kabupaten Karanganyar Surakarta. Skripsi. Universitas Slamet Riyadi. 2010.

15. Irwady. Penilaian Beban Kerja Perawat. 2007.www.scribd.com/doc/36043707/Pen ilaian-Beban-Kerja

16. Pemerintah Republik Indonesia. UndangUndang Kesehatan No 36 Tahun 2009 tentang Kesehatan. Jakarta. 2009.

17. Ilyas Y. Kinerja: Teori, Penilaian, dan Penelitian. Pusat Kajian Ekonomi Kesehatan FKM UI. Depok. 2004.

18. Nurnaningsih. Hubungan Beban Kerja Perawat terhadap Kinerja Perawat Dalam Pemberian Pelayanan Kesehatan di Ruang Rawat Inap Rumah Sakit Islam Faisal Makassar. Tesis. Universitas Hasanuddin. Makassar. 2012.
19. Minarsih. Hubungan Beban Kerja Perawat dengan Produktivitas Kerja Perawat di IRNA Non Bedah (Penyakit Dalam) RSUP Dr. M. Djamil Padang Tahun 2011. Tesis. FKM USU. Medan. 2011.

20. Sutarto A. Hubungan Motivasi Kompetensi dan Beban Kerja Dengan Kinerja Perawat di Instalasi Rawat Inap RSUD dr. Soediran Mangun Sumarso Wonogiri. Tesis. Universitas Sebelas Maret. Surakarta. 2016.

21. Manuho E, Warouw $H$, Hamel $R$. Hubungan Beban Kerja dengan Kinerja Perawat dalam Pemberian Asuhan Keperawatan di Instalasi Rawat Inap CI RSUP Prof. Dr. R.D. Kandou Manado. E-journal Keperawatan 3(2): 1-6. 2015. 